chemokine in the serum $(\mathrm{pg} / \mathrm{mL})$ of SLE patients compared to HC, respectively, included: sCX3CL1 (478.6 $\pm 46.19 ; 235.4 \pm 140.8)$ and MCP-1 $(2657 \pm 466.2 ; 648.5$ $\pm 69.6)(p<0.00001)$, MIP1B $(141.0 \pm 10.71 ; 79.31 \pm 10.69)(p<0.0003)$, and TNF $\alpha$ $(59.07 \pm 6.64 ; 29.31 \pm 3.15)(p<0.0041$. Additionally, the disease severity and endothelial dysfunction associated biomarker VEGF increased in SLE patients (445.6.3 $\pm 48.1 \mathrm{pg} / \mathrm{mL})$ compared to $\mathrm{HC}(231.8 \pm 47.03 \mathrm{pg} / \mathrm{mL})(\mathrm{p}<0.0069)$. Lastly, $\mathrm{HC}$ monocyte subsets were stimulated with TLR7 and 8 ligands and supernatants evaluated for the analytes described above, see table 2 .

Abstract FRI0291 - Table 1

\begin{tabular}{|c|c|c|c|c|c|c|c|}
\hline \multirow{2}{*}{\begin{tabular}{|c|}
$\begin{array}{c}\text { Monocyte } \\
\text { Subset }\end{array}$ \\
\end{tabular}} & \multirow{2}{*}{ Marker } & \multicolumn{2}{|c|}{ Healthy Control (Mean \pm SEM) } & \multicolumn{2}{|c|}{ SLE Patients (Mean \pm SEM) } & \multicolumn{2}{|c|}{ P-Value } \\
\hline & & Percentage & MFI & \begin{tabular}{|l} 
Percengate \\
\end{tabular} & MFI & Percentage & MFI \\
\hline $\mathrm{CD} 14^{+}$ & CCR1 & $71.18 \pm 5.31$ & $820.7 \pm 55.8$ & $71.81 \pm 6.425$ & $880.9 \pm 110.4$ & 0.799 & 0.775 \\
\hline $\mathrm{CD}_{16}{ }^{\circ}$ & CCR1 & $19.41 \pm 5.14$ & $1768.2 \pm 548.7$ & $33.90 \pm 7.86$ & $1716.6 \pm 473.9$ & 0.108 & 0.329 \\
\hline $\mathrm{CD} 14^{4} / \mathrm{CD} 16^{*}$ & CCR1 & $34.87 \pm 6.01$ & $1933.2 \pm 441.4$ & $49.50 \pm 7.13$ & $1935.1 \pm 396.4$ & 0.124 & 0.420 \\
\hline $\mathrm{CD} 14^{+}$ & $\mathrm{CD} 11 \mathrm{~b}$ & $97.58 \pm 0.59$ & $5289.5 \pm 410.9$ & $98.44 \pm 0.29$ & $6868.2 \pm 626.6$ & 0.985 & 0.007 \\
\hline${\mathrm{CD} 16^{\circ}}^{\circ}$ & $\mathrm{CD} 11 \mathrm{~b}$ & $55.22 \pm 4.48$ & $1289.6 \pm 146.6$ & $53.13 \pm 4.34$ & $2075.15 \pm 324.4$ & 0.819 & 0.021 \\
\hline $\mathrm{CD} 14^{\circ} / \mathrm{CD} 16^{\circ}$ & $\mathrm{CD} 11 \mathrm{~b}$ & $93.82 \pm 1.60$ & $4580.8 \pm 327.5$ & $93.72 \pm 2.32$ & $5640.9 \pm 579.0$ & 0.861 & 0.102 \\
\hline $\mathrm{CDN14}^{+}$ & $\mathrm{CD} 40$ & $7.61 \pm 2.72$ & $612.2 \pm 200.7$ & $8.06 \pm 3.08$ & $806.7 \pm 266.4$ & 0.861 & 0.333 \\
\hline $\mathrm{CD} 16^{*}$ & CD40 & $7.37 \pm 3.05$ & $1640.6 \pm 575.6$ & $15.65 \pm 6.09$ & $1466.1 \pm 473.6$ & 0.200 & 0.511 \\
\hline $\mathrm{CD} 14^{+} / \mathrm{CD} 16^{+}$ & $\mathrm{CD} 40$ & $9.77 \pm 2.92$ & $1116.7 \pm 225.2$ & $12.33 \pm 4.17$ & $1389.1 \pm 348.7$ & 0.643 & 0.389 \\
\hline $\mathrm{CD} 14^{+}$ & $\mathrm{CD} 163$ & $65.77 \pm 5.42$ & $1499.4 \pm 110.4$ & $85.24 \pm 3.08$ & $2198.3 \pm 171.0$ & 0.006 & 0.001 \\
\hline CD16 ${ }^{\circ}$ & $\mathrm{CD} 163$ & $15.21 \pm 3.06$ & $563.88 \pm 94.74$ & $24.08 \pm 3.34$ & $757.6 \pm 106.6$ & 0.022 & 0.022 \\
\hline $\mathrm{CD} 14^{\top} / \mathrm{CD} 16^{\circ}$ & $\mathrm{CD} 163$ & $61.00 \pm 4.96$ & $1358.0 \pm 108.6$ & $76.72 \pm 5.36$ & $2028.3 \pm 198.0$ & 0.014 & 0.014 \\
\hline $\mathrm{CD}_{14}{ }^{+}$ & CX3CR1 & $42.82 \pm 2.93$ & $796.2 \pm 70.58$ & $63.0 \pm 5.91$ & $1062 \pm 100.1$ & 0.005 & 0.047 \\
\hline CD16 ${ }^{\circ}$ & CX3CR1 & $86.47 \pm 2.53$ & $2471.8 \pm 223.5$ & $85.50 \pm 4.08$ & $2947.3 \pm 336.3$ & 0.742 & 0.378 \\
\hline & & & & & & & \\
\hline
\end{tabular}

Abstract FRI0291 - Table 2

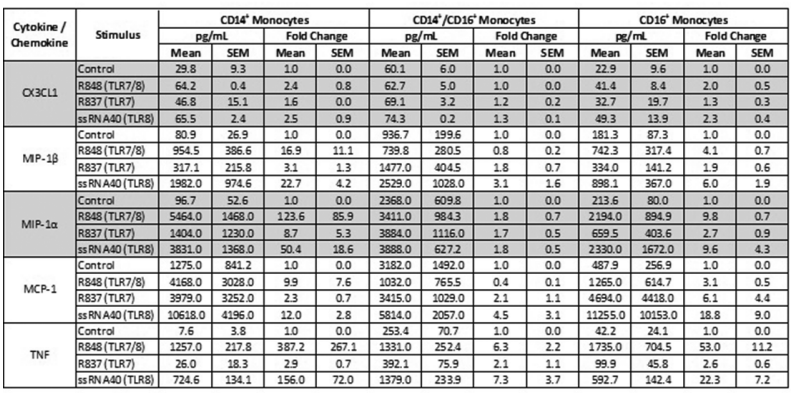

Conclusions: Cell surface markers of activation and adhesion increased in SLE monocyte subsets compared to $\mathrm{HC}$. In parallel, increased inflammatory cytokines and chemokines that attract monocytes to tissues were increased in the serum of these patients. Linking a possible source of this increase in serum analytes, HC monocyte subsets were stimulated with disease-relevant ligands and evaluated in culture. Along with increased monocyte expression of CX3CR1, preliminary data demonstrates an increase in CX3CL1 expression on endothelial progenitor cells (EPCs) and immature and mature circulating endothelial cells (iCECs and mCEC respectively) in active disease.

Disclosure of Interest: None declared

DOI: 10.1136/annrheumdis-2018-eular.3002

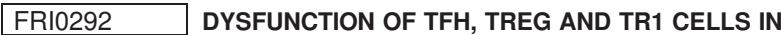 APOE-/- FASLGLD C57BL/6 MICE WITH LUPUS SYMPTOMS AND ATHEROSCLEROSIS}

S. Wang, G. Yao, L. Sun. Department of Rheumatology and Immunology, The Affiliated Drum Tower Hospital of Nanjing University Medical School, Nanjing, China

Background: Cardiovascular disease due to atherosclerosis is currently recognised as one of the leading causes of death among patients with systemic lupus erythematosus (SLE). It is well established that dysfunction of lymphocytes contribute to the pathogenesis of SLE. Recent studies also showed infiltration of several subsets of lymphocytes in atherosclerotic lesions and their various contributions to atherosclerosis were uncovered in experimental models and patients. However, the predominant and specific subsets of lymphocytes that play critical role in the pathogenesis of SLE patients with cardiovascular complications remained to be elucidated.

Objectives: This study aims to define the dominant population of lymphocytes in mice with combination of lupus and atherosclerosis.

Methods: The mouse model of accelerated atherosclerosis in lupus ( $\mathrm{ApoE}^{-/}$ Fas ${ }^{\text {gld }}$ B6 mice) was generated from apolipoprotein E-deficient $\left(\mathrm{apoE}^{-/-}\right)$and Fas $\left.\right|^{\text {gld }} \mathrm{C} 57 \mathrm{BL} / 6$ mice. The lupus-like autoimmunity and atherosclerotic lesions was evaluated. The lymphocytes of spleen and peripheral blood were analysed by flow cytometry.
Results: The results of PCR and sequencing showed that the double-mutant ApoE ${ }^{-/}$Fas $\left.\right|^{\text {gld }}$ B6 mice were generated. Spleens from 5 month-old $A p o E^{-/}$Fas ${ }^{\text {gld }}$ B6 mice were significantly enlarged compared with wild type mice (WT mice) $\mathrm{ApoE}^{-/-} \mathrm{Fas}^{\text {gld }} \mathrm{B} 6$ mice displayed a pattern of glomerulonephritis typically found in SLE and showed marked C3, IgG and IgM deposits in the glomeruli. Anti-dsDNA antibody and high levels of creatinine were detected in the serum of $\mathrm{ApoE}^{-/-} \mathrm{Fas}^{\text {gld }}$ B6 mice. These results indicated that the $\mathrm{ApoE}^{-/-} \mathrm{Fas}^{\text {gld }} \mathrm{B} 6$ mice have typical characteristics of SLE. Oil red O staining revealed that there was significantly increased atherosclerotic lesion area at the proximal aorta in $\mathrm{ApoE}^{-/-} \mathrm{Fas}^{\text {gld }} \mathrm{B} 6$ mice compared with WT mice (figure $1 \mathrm{a}, \mathrm{b}$ ). The frozen section of myocardium stained by oil red $\mathrm{O}$ revealed that lipid deposited in myocardial cells of $\mathrm{ApoE}^{-1}$ Fas ${ }^{\text {lld }}$ B6 mice (figure $1 \mathrm{c}, \mathrm{d}$ ). As excepted, total cholesterol, LDL cholesterol and triglyceride were significantly increased, while HDL cholesterol decreased in the double-mutant mice. These results indicated that $\mathrm{ApoE}^{-/} \mathrm{Fas}^{\text {gld }} \mathrm{B} 6$ mice had accelerated atherosclerosis. a

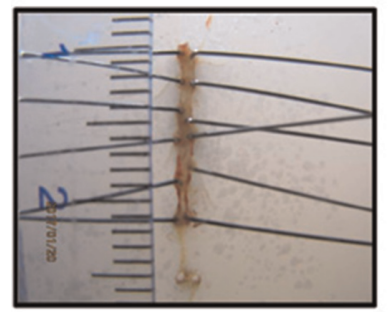

C

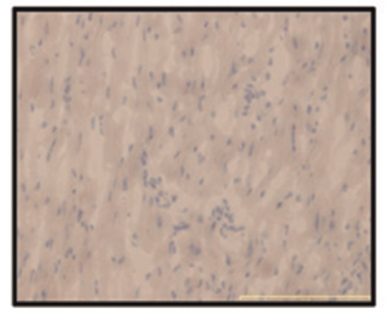

B6 b

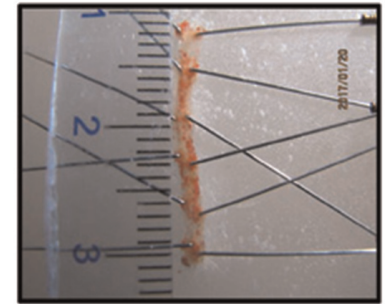

d

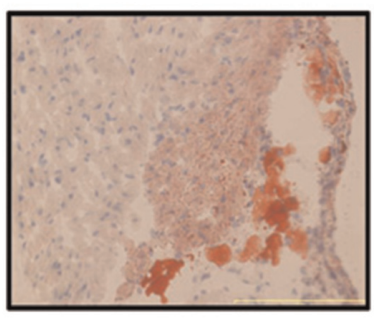

ApoE-/-gld
Conclusions: The ApoE ${ }^{-/-}$Fas $\left.\right|^{\text {gld }} \mathrm{B} 6$ mice simultaneous exhibit SLE and atherosclerosis characteristics. Our findings suggested that proinflammatory M1 macrophages and Tfh cells were increased, while the anti-inflammatory Treg and Tr1 cells were decreased and the imbalance of these cells and their releasing cytokines contributed to progression in atherosclerosis with SLE. Further studies may validate these cells as potential targets for treating SLE patients with atherosclerosis.

Disclosure of Interest: None declared

DOI: 10.1136/annrheumdis-2018-eular.2864

\section{FRI0293 IMBALANCE IN CIRCULATING SUBSETS OF INNATE LYMPHOID CELLS IS LINKED TO DISEASE ACTIVITY AND TYPE I INTERFERON SIGNATURE IN PRIMARY SJÖGREN'S SYNDROME}

S.L. Blokland ${ }^{1,2}$, L.L. van den Hoogen ${ }^{1,2}$, E.F. Leijten ${ }^{1,2}$, A.A. Kruize ${ }^{1}$, T. R. Radstake ${ }^{1,2}$, J.A. van Roon ${ }^{1,2}$. ${ }^{1}$ Rheumatology and Clinical Immunology; ${ }^{2}$ Laboratory of Translational Immunology, Umc Utrecht, Utrecht, Netherlands

Background: Recent studies indicate an important role for innate lymphoid cells (ILCs) in the pathophysiology of rheumatic diseases. In rheumatoid arthritis and spondyloarthropathies elevated numbers of subsets of ILCs have been found at the site of inflammation producing cytokines including IFN- $\gamma$ and IL-22 and in addition, group 3 ILC have been suggested to be involved in formation of ectopic lym phoid structures in rheumatic diseases, Shikhagaie Nat Rev Rheumatol 2017 Wenink A and R 2017). ILC3-like cells producing IL-22 have been found in the salivary glands of pSS patients. Ciccia ARD 2012 However, circulating ILC have not yet been studied in primary Sjögren's syndrome (pSS) and systemic lupus erythematosus (SLE). Furthermore, SLE and pSS are characterised by presence of a type I interferon (IFN) signature in a large proportion of the patients. Animal studies in HIV and asthma implicate type I IFN, produced by plasmacytoid dendritic cells (pDCs), to regulate the survival of group 2 and group 3 ILCs (ILC2 and 